\title{
CNS embryonal tumours: WHO 2016 and beyond
}

Jessica C Pickles ${ }^{1,2}$, Cynthia Hawkins ${ }^{3}$, Torsten Pietsch ${ }^{4}$, Thomas S Jacques ${ }^{1,2}$

\section{Affiliations:}

${ }^{1}$ Developmental Biology and Cancer Programme, UCL GOS Institute of Child Health, 30 Guilford Street, London WC1N 1EH, UK

${ }^{2}$ Department of Histopathology, Great Ormond Street Hospital for Children NHS Foundation Trust, Great Ormond Street, London WC1N 3JH, UK

${ }^{3}$ Division of Pathology, Hospital for Sick Children, University of Toronto, Toronto, Ontario, Canada

${ }^{4}$ Department of Neuropathology, Brain Tumor Reference Center of the DGNN, University of Bonn, Medical Center Sigmund-Freud, Bonn D-53105, Germany

Author for correspondence:

Dr Thomas S Jacques

UCL GOS Institute for Child Health, 30 Guilford Street, London WC1N 1EH, UK

Tel: $+44(0) 2078298663$

Fax: $+44(0) 2078314366$

Email: t.jacques@ucl.ac.uk

Keywords: embryonal tumour - medulloblastoma - embryonal tumour with multilayered rosettes - atypical teratoid/rhabdoid tumour - World Health Organisation

Words: 2584 (main body of text), figures: 1, tables: 2

Abbreviations: AT/RT atypical teratoid/rhabdoid tumour; CNS central nervous system; ETANTR embryonal tumour with abundant neuropil and true rosettes; ETMR embryonal tumour with multi-layered rosettes; FISH fluorescence in situ hybridisation; IHC immunohistochemistry; MB medulloblastoma; NOS not otherwise specified; PNET primitive neuro-ectodermal tumour; WHO World Health Organisation.

For publication in Neuropathology and Applied Neurobiology. 


\begin{abstract}
Embryonal tumours of the CNS present a significant clinical challenge. Many of these neoplasms affect young children, have a very high mortality and therapeutic strategies are often aggressive with poor long-term outcomes. There is a great need to accurately diagnose embryonal tumours, predict their outcome and adapt therapy to the individual patient's risk. For the first time in 2016, the WHO classification took into account molecular characteristics for the diagnosis of CNS tumours. This integration of histological features with genetic information has significantly changed the diagnostic work-up and reporting of tumours of the CNS. However, this remains challenging in embryonal tumours due to their previously unaccounted tumour heterogeneity. We describe the recent revisions made to the $4^{\text {th }}$ edition of the WHO classification of CNS tumours and review the main changes, whilst highlighting some of the more common diagnostic testing strategies.
\end{abstract}

\title{
Introduction
}

Since the last version of the WHO classification of tumours of the CNS in 2007 (1), molecular investigation has revolutionised our understanding of embryonal tumours of the CNS. This has largely been driven by genome-wide studies characterising prevalent genetic events and biological features. These have led to tumour reclassification, sub-typing and identification of novel entities $(2,3)$. However, many unanswered questions remain about the clinical impact of this knowledge, the best way to implement testing in clinical practice and how to manage the tumours that, despite molecular advances, defy standard classification.

Implementation of the integrated diagnosis for embryonal tumours

While the WHO classification 2007 relied on histological features only, the challenge of its update in 2016 was to integrate meaningful genetic information to enable a more precise classification, while maintaining continuity with the previous editions (4). This integrated diagnosis would be presented in a layered format; including the histological diagnosis, WHO grade, molecular genetic information and ultimately the integrated diagnosis. The value of this approach is clearly illustrated in embryonal tumours, in particular medulloblastoma, where the combination of molecular and histological data provides discrete diagnostic information (Figure 1) $(2,4)$.

For non-medulloblastoma and non-AT/RT embryonal tumours, diagnostic classification has been a major challenge. These tumours were formerly called supratentorial or CNS-primitive neuro-ectodermal tumours (PNET) (1). Up until now, "CNS-PNET" has been used as an umbrella term for a range of biologically different tumours. Several molecular profiling studies 
on tumours previously diagnosed as CNS-PNET showed that a wide range of biologically different tumours existed within this entity, some of which were incorrectly assigned (5-7). These encompassed other well-recognised tumour types (e.g. high-grade gliomas and sarcomas), recently redefined entities (e.g. embryonal tumour with multi-layered rosettes, ETMR) as well as novel tumour types (2).

The clinical importance of molecular classification

The correct diagnosis of paediatric tumours is critical for their treatment because of the balance required between achieving a long-term cure and avoiding treatment related disability in survivors. It is essential to recognise those children with a poor prognosis who can either receive escalated treatment or be offered palliative care, versus those with a good prognosis for whom treatment might be reduced to prevent long term complications. This is perhaps again best illustrated in medulloblastoma, where overall survival rates are $65-70 \%$ after 5 years (8). However, there are significant cognitive, endocrine and neurological complications in the majority of survivors $(9,10)$. These individuals are significantly less likely to complete education and live independently when compared to age matched controls.

\section{Medulloblastoma}

Four medulloblastoma genetic entities are now recognised by WHO 2016 classification (4). These are: 1) WNT-activated (MB $\mathrm{WNT}_{\mathrm{WN}}$ ); 2) SHH-activated (MB $\left.\mathrm{MHH}_{\mathrm{SH}}\right)$, TP53 wildtype; 3) SHHactivated (MB $\mathrm{MHH}_{\mathrm{SH}}$, TP53 mutant; 4) Non-WNT/Non-SHH medulloblastoma. The latter can be further subdivided with DNA methylation or mRNA expression profiling into "group 3" and "group 4" (11). These variants are considered provisional because it is not absolutely clear to what extent they represent distinct diseases, multiple subtypes or variants of a single entity. Table 1 describes their most commonly associated genetic changes and the diagnostic histological variants. It is essential that according to the revised WHO classification 2016, every diagnosis of medulloblastoma should result in an integrated diagnosis with a histological part and a genetically defined part as both aspects provide clinically important information (12).

\section{Genetically defined medulloblastoma}

Around $10 \%$ of medulloblastomas fall into the $\mathrm{MB}_{\mathrm{WNT}}$ subgroup and most display classic histology (3). Over $90 \%$ of $\mathrm{MB}_{\mathrm{WNT}}$ are associated with point mutations in exon 3 of the CTNNB1 (beta-catenin) gene. Mutations in CTNNB1 or (at lower frequencies) other components of the WNT signalling pathway (e.g. AXIN1, AXIN2 and APC) lead to the pathway's constitutive activation with accumulation of the ß-catenin protein in the nucleus, identifiable by immunohistochemistry (IHC). Monosomy for chromosome 6 is present in about 
$85 \%$ of cases, and may aid in supporting a diagnosis of $\mathrm{MB}_{\mathrm{WNT}}$. Importantly, $\mathrm{MB}_{\mathrm{WNT}}$ has an excellent overall prognosis in children (>90\% survival) following surgery and current treatment protocols (3). Clinical trials are underway in Europe and North America to determine if treatment intensity can be safely reduced for these tumours, thus also reducing treatmentrelated long term developmental and cognitive disabilities without affecting survival rates (13). However, it should be noted that the adults with $M_{W N T}$ do not show the same prognostic advantage (14).

Approximately $30 \%$ of medulloblastomas show activation of the sonic hedgehog signalling pathway signalling (3). The status of TP53 further divides $M_{S H H}$ into two entities with completely different clinical outcomes (15). $\mathrm{MB}_{\mathrm{SHH}}$ tumours with TP53 mutations have a dismal prognosis and are considered very high-risk. A significant number of these patients $(\sim 50 \%$ in one series) carry germline mutations in TP53 and their treatment is especially challenging due to their susceptibility to secondary tumours following radiotherapy (16). $\mathrm{MB}_{\mathrm{SHH}}$ patients without TP53 mutations are considered lower-risk but many of these, particularly young children, carry germline mutations in PTCH1 or SUFU which can alter treatment strategies (17). Therefore, genetic counselling should be considered for all families with children with medulloblastomas with $\mathrm{SHH}$ activation.

Non-WNT/non-SHH medulloblastomas are provisionally divided into group 3 (MBgrp3) and group $4\left(\mathrm{MB}_{\mathrm{grp}}\right)$, which account for approximately $20 \%$ and $40 \%$ of all medulloblastomas respectively. However, the diagnostic status of the non-WNT/non-SHH subtypes is likely to develop over the next few years.

\section{Histologically defined medulloblastoma}

The histological subtypes of medulloblastoma have not changed in a major way in the update of the $4^{\text {th }}$ edition of the WHO classification (see Table 1) $(1,4)$. Large cell and anaplastic variants have been combined into a single entity, reflecting their frequent coexistence together with the clinically uniform approach to this group. This tumour type has a very poor prognosis. Furthermore, the melanotic and myoblastic forms have been regarded as tissue patterns rather than specific entities, reflecting their extreme rarity. Finally, an emphasis is made in defining the desmoplastic/nodular medulloblastoma subtype by reticulin staining. The key feature in defining this subtype is that the nodules are surrounded by reticulin-rich tissue. This allows distinction between classic medulloblastoma with a biphasic architecture, which has nodules but no desmoplasia (regarded as a variant of classic medulloblastoma) from desmoplastic/nodular medulloblastoma which has not only nodular architecture but extensive reticulin rich desmoplasia between the nodules. 
Overlap exists between molecular and histological subtypes; for example, MBWNT almost always has classic histology, while desmoplastic/nodular MB and MB with extensive nodularity are $\mathrm{MB}_{\mathrm{SHH}}$. However, $\mathrm{MB}_{\mathrm{SHH}}$ can have classic or anaplastic histology and occasional anaplastic $\mathrm{MB}_{\mathrm{WNT}}$ cases have been reported. The interplay between molecular and histological subtype is imperfectly understood and their relationship to outcome is yet to be addressed in a systematic way.

\section{Prognostic markers of medulloblastoma}

In addition to the molecular techniques needed to classify medulloblastoma, there are molecular markers that provide additional prognostic information. The two markers for which there is the best data and are offered routinely are amplification of $M Y C$ or $M Y C N$; presence of either of these has been associated with a worse outcome (18). However, recent data suggests that the prognostic significance of these markers depends on the genetically defined medulloblastoma entity. MYC amplification is usually seen in non-WNT/non-SHH medulloblastomas and these patients have a poor prognosis. While amplification of $M Y C N$ in $\mathrm{MB}_{\mathrm{SHH}}$ indicates a very poor outcome, its prognostic value in non-WNT/non-SHH medulloblastomas is less clear (8).

\section{Recent classification of medulloblastoma}

Larger datasets have recently suggested more medulloblastoma subgroups than the current WHO recognises. One study proposes seven genetic entities based on clustering algorithms, with each existing group except $\mathrm{MB}_{\mathrm{WNT}}$ being further divided into high and low-risk (8); while another suggests a total of 12 subgroups based on the integration of transcriptomic and methylation data (19). Further exploration of the clinical significance of these subtypes will reveal how the next WHO classification may need to be adapted.

\section{Relapsed medulloblastoma}

Relapsed medulloblastoma has a uniformly bad outcome (20). There is a great need to understand the tumours at the point of relapse, especially their mechanisms of resistance. At relapse, medulloblastoma has been shown to maintain the same genetically-defined subtype but may change morphological subtype, for example towards a more anaplastic pathology (21). Furthermore, acquisition of additional genetic events at relapse can also have a clinical impact. Combined abnormalities of MYC and TP53 occur in a subpopulation of relapsed medulloblastoma and are associated with a very poor prognosis (22). In mouse models, these tumours can be targeted therapeutically and suggests that it will be important 
to undertake diagnostic testing on the relapsed tumour both to predict outcome but also to predict response to treatment.

Spatial heterogeneity studies in medulloblastoma suggest that actionable drug targets (i.e. mutations) are unevenly distributed across the tumour mass (23). This indicates that subclonal events underlying tumour heterogeneity may be responsible for drug resistance, which also puts into question the efficacy of targeted monotherapies, especially in the presence of subclonal events at relapse (24).

\section{Non-medulloblastoma embryonal tumours}

\section{Embryonal tumour with multilayered rosettes (ETMR)}

The recognition of embryonal tumour with multilayered rosettes, C19MC-altered as a distinct tumour type is a major change in recent years. Historically, these tumours have been described under a range of morphological entities: embryonal tumour with abundant neuropil and true rosettes (ETANTR), ependymoblastoma and medulloepithelioma (Figure 1) (25). These tumours harbour an amplification on chromosome 19 of a large miRNA cluster (C19MC) $(26,27)$, which can be readily identified by FISH. This region is associated with a suspected area of genetic instability, leading to the fusion of TTYH1 with C19MC (28). Although not specific to ETMRs, LIN28A is typically expressed in ETMRs (LIN28A is also expressed in some germinomas and occasionally in AT/RT) and detection by IHC is a useful screening test to alert to the possibility of an ETMR and the need for C19MC amplification testing (29). The clinical behaviour of ETMR is typically that of rapid progression and in most cases, they are unresponsive to conventional therapy. Therefore, immunohistochemically, molecularly and clinically, ETMRs form a relatively uniform group of infant CNS tumours with generally abysmal outcomes. Many of the tumours previously called medulloepithelioma will fall into this group but there are medulloepitheliomas that while expressing LIN28A, lack C19MC amplification (6) which according to the current WHO classification should be regarded as a separate entity (4). Finally, ETMR, NOS should be assigned when multilayered ependymoblastic rosettes are identified, but there is no C19MC alteration detected or when testing for the alteration has not been undertaken.

\section{Atypical teratoid/rhabdoid tumours (AT/RT)}

AT/RT has been a well-established tumour entity for many years and has been recognised in previous editions of the WHO (1). However, the demonstration of SMARCB1 (INI1) loss or very rarely loss of SMARCA4 (BRG1), also a component of the SWI/SNF chromatin remodelling complex, has become a diagnostic requirement (Table 2). This reflects the long- 
accepted definition of these as high-grade CNS tumours characterised by inactivation of these genes (30). In instances where tumour morphology is consistent with AT/RT but displays positive nuclear staining for SMARCB1, SMARCA4 loss should be confirmed.

Several studies have indicated the presence of molecular AT/RT subtypes associated with differences in clinical and treatment responses and consensus is underway in order to better inform molecular stratification of these tumours and determine if this will become clinically relevant $(31,32)$. A separate category for CNS embryonal tumour with rhabdoid features has been retained for tumours in which either the genes are intact or their status cannot be determined (4).

\section{Other CNS embryonal tumours}

The generic term 'embryonal tumours' has replaced CNS primitive neuroectodermal tumours (CNS-PNET) in the WHO 2016 classification (Figure 1). This separates the current terminology from historical concepts of PNET covering a diverse range of CNS tumours (medulloblastoma and supratentorial PNET) and from potential confusion from tumours of the same name arising outside the nervous system (e.g. Ewing's type sarcoma/peripheral PNET) $(33,34)$. CNS embryonal tumours include the following morphological subtypes: medulloepithelioma, CNS neuroblastoma, CNS ganglioneuroblastoma and CNS embryonal tumour, NOS. The diagnosis of embryonal tumour therefore requires active exclusion of other embryonic specific entities (e.g. ETMR and AT/RT). Furthermore, a proportion of tumours previously described as CNS-PNET can be re-diagnosed as a number of other tumour types (e.g. glioblastoma, ependymoma, Ewing's sarcoma) $(35,36)$ and these must also be excluded. Table 2 includes an overview of useful diagnostic IHC testing that can be performed with respect to making a diagnosis of embryonal tumour.

Recent data has defined four tumour entities based on methylation profiling; some of which historically would have been diagnosed as CNS-PNET, along with other tumour types (36). Sequencing for recurrent mutations identified common gene fusions in a proportion of cases belonging to these subgroups. CNS neuroblastoma with FOXR2 activation (NB-FOXR2) was characterised by FOXR2 fusions, which may come to encompass CNS neuroblastomas and CNS ganglioneuroblastomas. High-grade neuroepithelial tumours with MN1 alteration (HGNET-MN1) typically contain MN1 fusions (identifiable by FISH), although a robust immunohistochemical marker is missing. Morphological similarities have been noted to the glial neoplasm, astroblastoma. The Ewing's sarcoma family tumour with CIC alteration (EFT$\mathrm{CIC}$ ) have $\mathrm{CIC}$ structural variants, which can be detected by break-apart FISH and are typically characterised by positive NUTM1 nuclear staining. Finally, the BCOR-altered neuroepithelial 
tumours are defined by a $B C O R$ duplication (and rarely point mutations) in exon 15 . Both these entities may reflect mesenchymal/sarcomatous tumours which occur in other parts of the body and not limited to the CNS.

Due to the rarity of these novel tumour entities, risk stratification, assessment of clinical significance and selection of appropriate therapeutic strategies will be immensely challenging. However, preliminary clinical data from a total of 31 patients did suggest differences in survival rates; with the HGNET-MN1 group associated with the best prognosis (36).

\section{Pineoblastoma}

Pineoblastomas histologically resemble CNS embryonal tumours but arise from the pineal gland. They are treated according to the same protocols as embryonal tumours and show poor prognosis, although studies suggest that adults and children do better than infant cases $(37,38)$. Histologically, they are composed of sheets of densely packed hyperchromatic cells with strong staining for neuronal markers (e.g. synaptophysin). Cytogenetic studies describe pineoblastomas as having fewer alterations compared with other embryonal tumours (39) and similarly, recurrent genetic changes beyond germline RB1 mutations (linked to retinoblastoma) and DICER1 are yet to be identified (40). Retinoblastoma and pineoblastoma can coincide in patients with trilateral retinoblastoma due to common developmental lineages and the retinal transcription factor, CRX has been identified as a possible marker of some pineal tumours, although its interpretation may be somewhat challenging depending on the age and quality of the tissue $(41,42)$.

Pineal anlage tumours are very rare pineal tumours with heterologous differentiation alongside a primitive neuroectodermal component. They typically contain melanin and the heterologous elements may exhibit skeletal muscle or chondroid differentiation (43). There are no molecular studies that indicate whether there are distinctive diagnostic molecular features of this tumour.

\section{Pituitary blastoma}

An extremely rare entity that is considered an embryonal tumour of the pituitary gland is the pituitary blastoma (44). There are 13 infant cases described in the literature and a germ-line mutation in DICER1 is reported to be a key predisposing event (45).

\section{Concluding remarks}

In terms of diagnostic approaches, transparency is needed on how molecular and immunohistochemical tests are ideally performed and interpreted for optimal guidance of therapeutic management. For medulloblastoma, recent guidelines for clinical diagnosis have 
been published (46) and similar information should be made available for the other entities. DNA methylation and transcriptomic based clustering approaches are proving greatly valuable but are not widely accessible, nor are such methods fully validated for clinical diagnosis. Obviously, insufficient material for genetic screening may lead to uncertainty and not all centres may currently have access to the necessary facilities to implement a fully integrated diagnosis.

Since the publication of the WHO 2016 classification, additional heterogeneity within the medulloblastoma subtypes and other embryonal tumour groups has already been identified $(8,19,36)$ and we anticipate additional molecular findings are likely to influence the next WHO revision. As existing tumour groups are further sub-divided into distinct groups, the rarity of these tumours will challenge risk-stratification and assignment of appropriate therapeutic strategies, while archival studies will be key in identifying defining molecular signatures of currently unclassifiable tumours.

\section{Acknowledgements}

TSJ was in receipt of funding from the Great Ormond Street Hospital Children's Charity, the Brain Tumour Charity, Children with Cancer UK and NIHR. This report is independent research supported by the National Institute for Health Research Great Ormond Street Hospital Biomedical Research Centre. The views expressed in this publication are those of the author(s) and not necessarily those of the NHS, the National Institute for Health Research or the Department of Health. JCP, CH, TP and TSJ are co-authors and agree with the content of this manuscript. We thank Pieter Wesseling for putting together the article's figure.

\section{The authors have no conflict of interest to declare}




\section{Legends}

Figure 1. Summary of the major changes in the WHO 2016 classification for the diagnosis of CNS embryonal tumours

In the 2007 WHO classification tumours were histologically defined. In the current edition, an integrated diagnosis combines histology with genetically defined tumours. For embryonal tumours, this has meant four new genetic subgroups of medulloblastoma. The CNS-PNET entity is no longer recognised, instead ETMRs form their own embryonal entries, while any remaining tumours are currently classified based on histology alone and fall under "other embryonal tumours". This group of genetically undefined tumours contains medulloepithelioma, CNS neuroblastoma, CNS ganglioneuroblastoma and CNS embryonal tumour, NOS. *: provisional subentity, NOS: not otherwise specified.

Table 1. WHO 2016 classification of medulloblastoma subtypes, characterised by genetic and histological features

The most common features associated with each molecular $(A)$ and histological $(B)$ subgroup for medulloblastoma are described. The tables aid as a good basis for completing an integrated diagnosis of medulloblastoma. For a more comprehensive list, the reader is advised to refer to the WHO 2016 classification, pages 184-185.

\section{Table 2. WHO 2016 classification of non-medulloblastoma embryonal tumours}

The key diagnostic features associated with non-medulloblastoma embryonal tumours are described. For a diagnosis of embryonal tumours, NOS it is necessary to actively exclude alternative possibilities (e.g. ETMR, high-grade glioma, ependymoma etc.) and if possible, it may be worth considering a DNA methylation array to see if the tumour matches previously identified molecular profiles. For more details, the reader is advised to refer to the WHO 2016 classification, pages 201-212. 


\section{References}

1. Louis DN OH, Wiestler OD, Cavenee WK WHO Classification of tumours of the central nervous system. . Lyon IARC; 2007.

2. Louis DN, Perry A, Reifenberger G, von Deimling A, Figarella-Branger D, Cavenee WK, Ohgaki H, Wiestler OD, Kleihues P, Ellison DW. The 2016 World Health Organization Classification of Tumors of the Central Nervous System: a summary. Acta Neuropathol. 2016;131(6):803-20.

3. Gajjar A, Pfister SM, Taylor MD, Gilbertson RJ. Molecular insights into pediatric brain tumors have the potential to transform therapy. Clinical cancer research : an official journal of the American Association for Cancer Research. 2014;20(22):5630-40.

4. Louis DN OH, Wiestler OD, Cavenee WK, Ellison DW, Figarella-Branger D, Perry A, Reifenberger G, Von Deimling A. WHO Classification of Tumours of the Central Nervous System Lyon IARC Press; 2016.

5. Picard D, Miller S, Hawkins CE, Bouffet E, Rogers HA, Chan TS, Kim SK, Ra YS, Fangusaro J, Korshunov A, Toledano H, Nakamura H, Hayden JT, Chan J, Lafay-Cousin L, Hu P, Fan X, Muraszko KM, Pomeroy SL, Lau CC, Ng HK, Jones C, Van Meter T, Clifford SC, Eberhart C, Gajjar A, Pfister SM, Grundy RG, Huang A. Markers of survival and metastatic potential in childhood CNS primitive neuroectodermal brain tumours: an integrative genomic analysis. Lancet Oncol. 2012;13(8):838-48.

6. Spence T, Sin-Chan P, Picard D, Barszczyk M, Hoss K, Lu M, Kim SK, Ra YS, Nakamura H, Fangusaro J, Hwang E, Kiehna E, Toledano H, Wang Y, Shi Q, Johnston D, Michaud J, La Spina M, Buccoliero AM, Adamek D, Camelo-Piragua S, Peter Collins V, Jones C, Kabbara N, Jurdi N, Varlet P, Perry A, Scharnhorst D, Fan X, Muraszko KM, Eberhart CG, Ng HK, Gururangan S, Van Meter T, Remke M, Lafay-Cousin L, Chan JA, Sirachainan N, Pomeroy SL, Clifford SC, Gajjar A, Shago M, Halliday W, Taylor MD, Grundy R, Lau CC, Phillips J, Bouffet E, Dirks PB, Hawkins CE, Huang A. CNSPNETs with C19MC amplification and/or LIN28 expression comprise a distinct histogenetic diagnostic and therapeutic entity. Acta Neuropathol. 2014;128(2):291-303.

7. Schwalbe EC, Hayden JT, Rogers HA, Miller S, Lindsey JC, Hill RM, Nicholson SL, Kilday JP, Adamowicz-Brice M, Storer L, Jacques TS, Robson K, Lowe J, Williamson D, Grundy RG, Bailey S, Clifford SC. Histologically defined central nervous system primitive neuro-ectodermal tumours (CNSPNETs) display heterogeneous DNA methylation profiles and show relationships to other paediatric brain tumour types. Acta Neuropathol. 2013;126(6):943-6.

8. Schwalbe EC, Lindsey JC, Nakjang S, Crosier S, Smith AJ, Hicks D, Rafiee G, Hill RM, lliasova A, Stone T, Pizer B, Michalski A, Joshi A, Wharton SB, Jacques TS, Bailey S, Williamson D, Clifford SC. Novel molecular subgroups for clinical classification and outcome prediction in childhood medulloblastoma: a cohort study. Lancet Oncol. 2017;18(7):958-71.

9. King AA, Seidel K, Di C, Leisenring WM, Perkins SM, Krull KR, Sklar CA, Green DM, Armstrong GT, Zeltzer LK, Wells E, Stovall M, Ullrich NJ, Oeffinger KC, Robison LL, Packer RJ. Long-term neurologic health and psychosocial function of adult survivors of childhood medulloblastoma/PNET: a report from the Childhood Cancer Survivor Study. Neuro Oncol. 2017;19(5):689-98.

10. King AA, Perkins SM, Seidel K, Di C, Leisenring WM, Krull KR, Sklar CA, Green DM, Armstrong GT, Zeltzer LK, Wells E, Stovall M, Ullrich N, Oeffinger KC, Robison LL, Packer R. Health and functional status of long-term adult medulloblastoma/PNet survivors: A report from the Childhood Cancer Survivor Study. Journal of Clinical Oncology. 2014;32(15_suppl):9515-.

11. Taylor MD, Northcott PA, Korshunov A, Remke M, Cho YJ, Clifford SC, Eberhart CG, Parsons DW, Rutkowski S, Gajjar A, Ellison DW, Lichter P, Gilbertson RJ, Pomeroy SL, Kool M, Pfister SM. Molecular subgroups of medulloblastoma: the current consensus. Acta Neuropathol. 2012;123(4):46572.

12. Louis DN, Perry A, Burger P, Ellison DW, Reifenberger G, von Deimling A, Aldape K, Brat D, Collins VP, Eberhart C, Figarella-Branger D, Fuller GN, Giangaspero F, Giannini C, Hawkins C, Kleihues P, Korshunov A, Kros JM, Beatriz Lopes M, Ng HK, Ohgaki H, Paulus W, Pietsch T, Rosenblum M, Rushing E, Soylemezoglu F, Wiestler O, Wesseling P. International Society Of Neuropathology--Haarlem consensus guidelines for nervous system tumor classification and grading. Brain Pathol. 2014;24(5):429-35.

13. Pizer BL, Clifford SC. The potential impact of tumour biology on improved clinical practice for medulloblastoma: progress towards biologically driven clinical trials. British journal of neurosurgery. 2009;23(4):364-75.

14. Zhao F, Ohgaki H, Xu L, Giangaspero F, Li C, Li P, Yang Z, Wang B, Wang X, Wang Z, Ai L, Zhang J, Luo L, Liu P. Molecular subgroups of adult medulloblastoma: a long-term single-institution study. Neuro Oncol. 2016;18(7):982-90. 
15. Zhukova N, Ramaswamy V, Remke M, Pfaff E, Shih DJ, Martin DC, Castelo-Branco P, Baskin B, Ray PN, Bouffet E, von Bueren AO, Jones DT, Northcott PA, Kool M, Sturm D, Pugh TJ, Pomeroy SL, Cho YJ, Pietsch T, Gessi M, Rutkowski S, Bognar L, Klekner A, Cho BK, Kim SK, Wang KC, Eberhart CG, Fevre-Montange M, Fouladi M, French PJ, Kros M, Grajkowska WA, Gupta N, Weiss WA, Hauser P, Jabado N, Jouvet A, Jung S, Kumabe T, Lach B, Leonard JR, Rubin JB, Liau LM, Massimi L, Pollack IF, Shin Ra Y, Van Meir EG, Zitterbart K, Schuller U, Hill RM, Lindsey JC, Schwalbe EC, Bailey S, Ellison DW, Hawkins C, Malkin D, Clifford SC, Korshunov A, Pfister S, Taylor MD, Tabori U. Subgroup-specific prognostic implications of TP53 mutation in medulloblastoma. Journal of clinical oncology : official journal of the American Society of Clinical Oncology. 2013;31(23):2927-35.

16. Rausch T, Jones DT, Zapatka M, Stutz AM, Zichner T, Weischenfeldt J, Jager N, Remke M, Shih D, Northcott PA, Pfaff E, Tica J, Wang Q, Massimi L, Witt H, Bender S, Pleier S, Cin H, Hawkins C, Beck C, von Deimling A, Hans V, Brors B, Eils R, Scheurlen W, Blake J, Benes V, Kulozik AE, Witt O, Martin D, Zhang C, Porat R, Merino DM, Wasserman J, Jabado N, Fontebasso A, Bullinger L, Rucker FG, Dohner K, Dohner H, Koster J, Molenaar JJ, Versteeg R, Kool M, Tabori U, Malkin D, Korshunov A, Taylor MD, Lichter P, Pfister SM, Korbel JO. Genome sequencing of pediatric medulloblastoma links catastrophic DNA rearrangements with TP53 mutations. Cell. 2012;148(1-2):59-71.

17. Kool M, Jones DT, Jager N, Northcott PA, Pugh TJ, Hovestadt V, Piro RM, Esparza LA, Markant SL, Remke M, Milde T, Bourdeaut F, Ryzhova M, Sturm D, Pfaff E, Stark S, Hutter S, Seker-Cin H, Johann P, Bender S, Schmidt C, Rausch T, Shih D, Reimand J, Sieber L, Wittmann A, Linke L, Witt H, Weber UD, Zapatka M, Konig R, Beroukhim R, Bergthold G, van Sluis P, Volckmann R, Koster J, Versteeg R, Schmidt S, Wolf S, Lawerenz C, Bartholomae CC, von Kalle C, Unterberg A, Herold-Mende C, Hofer S, Kulozik AE, von Deimling A, Scheurlen W, Felsberg J, Reifenberger G, Hasselblatt M, Crawford JR, Grant GA, Jabado N, Perry A, Cowdrey C, Croul S, Zadeh G, Korbel JO, Doz F, Delattre O, Bader GD, McCabe MG, Collins VP, Kieran MW, Cho YJ, Pomeroy SL, Witt O, Brors B, Taylor MD, Schuller U, Korshunov A, Eils R, Wechsler-Reya RJ, Lichter P, Pfister SM. Genome sequencing of SHH medulloblastoma predicts genotype-related response to smoothened inhibition. Cancer Cell. 2014;25(3):393-405.

18. Pfister S, Remke M, Benner A, Mendrzyk F, Toedt G, Felsberg J, Wittmann A, Devens F, Gerber NU, Joos S, Kulozik A, Reifenberger G, Rutkowski S, Wiestler OD, Radlwimmer B, Scheurlen W, Lichter $P$, Korshunov A. Outcome prediction in pediatric medulloblastoma based on DNA copynumber aberrations of chromosomes $6 q$ and $17 q$ and the MYC and MYCN loci. Journal of clinical oncology : official journal of the American Society of Clinical Oncology. 2009;27(10):1627-36.

19. Cavalli FMG, Remke M, Rampasek L, Peacock J, Shih DJH, Luu B, Garzia L, Torchia J, Nor C, Morrissy AS, Agnihotri S, Thompson YY, Kuzan-Fischer CM, Farooq H, Isaev K, Daniels C, Cho BK, Kim SK, Wang KC, Lee JY, Grajkowska WA, Perek-Polnik M, Vasiljevic A, Faure-Conter C, Jouvet A, Giannini C, Nageswara Rao AA, Li KKW, Ng HK, Eberhart CG, Pollack IF, Hamilton RL, Gillespie GY, Olson JM, Leary S, Weiss WA, Lach B, Chambless LB, Thompson RC, Cooper MK, Vibhakar R, Hauser P, van Veelen MC, Kros JM, French PJ, Ra YS, Kumabe T, Lopez-Aguilar E, Zitterbart K, Sterba J, Finocchiaro G, Massimino M, Van Meir EG, Osuka S, Shofuda T, Klekner A, Zollo M, Leonard JR, Rubin JB, Jabado N, Albrecht S, Mora J, Van Meter TE, Jung S, Moore AS, Hallahan AR, Chan JA, Tirapelli DPC, Carlotti CG, Fouladi M, Pimentel J, Faria CC, Saad AG, Massimi L, Liau LM, Wheeler H, Nakamura H, Elbabaa SK, Perezpena-Diazconti M, Chico Ponce de Leon F, Robinson S, Zapotocky M, Lassaletta A, Huang A, Hawkins CE, Tabori U, Bouffet E, Bartels U, Dirks PB, Rutka JT, Bader GD, Reimand J, Goldenberg A, Ramaswamy V, Taylor MD. Intertumoral Heterogeneity within Medulloblastoma Subgroups. Cancer Cell. 2017;31(6):737-54.e6.

20. Koschmann C, Bloom K, Upadhyaya S, Geyer JR, Leary SE. Survival After Relapse of Medulloblastoma. J Pediatr Hematol Oncol. 2016;38(4):269-73.

21. Ramaswamy V, Remke M, Bouffet E, Faria CC, Perreault S, Cho YJ, Shih DJ, Luu B, Dubuc AM, Northcott PA, Schuller U, Gururangan S, McLendon R, Bigner D, Fouladi M, Ligon KL, Pomeroy SL, Dunn S, Triscott J, Jabado N, Fontebasso A, Jones DT, Kool M, Karajannis MA, Gardner SL, Zagzag D, Nunes S, Pimentel J, Mora J, Lipp E, Walter AW, Ryzhova M, Zheludkova O, Kumirova E, Alshami J, Croul SE, Rutka JT, Hawkins C, Tabori U, Codispoti KE, Packer RJ, Pfister SM, Korshunov A, Taylor MD. Recurrence patterns across medulloblastoma subgroups: an integrated clinical and molecular analysis. Lancet Oncol. 2013;14(12):1200-7.

22. Hill RM, Kuijper S, Lindsey JC, Petrie K, Schwalbe EC, Barker K, Boult JK, Williamson D, Ahmad Z, Hallsworth A, Ryan SL, Poon E, Robinson SP, Ruddle R, Raynaud FI, Howell L, Kwok C, Joshi A, Nicholson SL, Crosier S, Ellison DW, Wharton SB, Robson K, Michalski A, Hargrave D, Jacques TS, Pizer B, Bailey S, Swartling FJ, Weiss WA, Chesler L, Clifford SC. Combined MYC and P53 defects emerge at medulloblastoma relapse and define rapidly progressive, therapeutically targetable disease. Cancer Cell. 2015;27(1):72-84. 
23. Morrissy AS, Cavalli FMG, Remke M, Ramaswamy V, Shih DJH, Holgado BL, Farooq H, Donovan LK, Garzia L, Agnihotri S, Kiehna EN, Mercier E, Mayoh C, Papillon-Cavanagh S, Nikbakht H, Gayden T, Torchia J, Picard D, Merino DM, Vladoiu M, Luu B, Wu X, Daniels C, Horswell S, Thompson YY, Hovestadt V, Northcott PA, Jones DTW, Peacock J, Wang X, Mack SC, Reimand J, Albrecht S, Fontebasso AM, Thiessen N, Li Y, Schein JE, Lee D, Carlsen R, Mayo M, Tse K, Tam A, Dhalla N, Ally A, Chuah E, Cheng Y, Plettner P, Li HI, Corbett RD, Wong T, Long W, Loukides J, Buczkowicz P, Hawkins CE, Tabori U, Rood BR, Myseros JS, Packer RJ, Korshunov A, Lichter P, Kool M, Pfister SM, Schuller U, Dirks P, Huang A, Bouffet E, Rutka JT, Bader GD, Swanton C, Ma Y, Moore RA, Mungall AJ, Majewski J, Jones SJM, Das S, Malkin D, Jabado N, Marra MA, Taylor MD. Spatial heterogeneity in medulloblastoma. Nat Genet. 2017;49(5):780-8.

24. Morrissy AS, Garzia L, Shih DJ, Zuyderduyn S, Huang X, Skowron P, Remke M, Cavalli FM, Ramaswamy V, Lindsay PE, Jelveh S, Donovan LK, Wang X, Luu B, Zayne K, Li Y, Mayoh C, Thiessen N, Mercier E, Mungall KL, Ma Y, Tse K, Zeng T, Shumansky K, Roth AJ, Shah S, Farooq H, Kijima N, Holgado BL, Lee JJ, Matan-Lithwick S, Liu J, Mack SC, Manno A, Michealraj KA, Nor C, Peacock J, Qin L, Reimand J, Rolider A, Thompson YY, Wu X, Pugh T, Ally A, Bilenky M, Butterfield YS, Carlsen R, Cheng Y, Chuah E, Corbett RD, Dhalla N, He A, Lee D, Li HI, Long W, Mayo M, Plettner P, Qian JQ, Schein JE, Tam A, Wong T, Birol I, Zhao Y, Faria CC, Pimentel J, Nunes S, Shalaby T, Grotzer M, Pollack IF, Hamilton RL, Li XN, Bendel AE, Fults DW, Walter AW, Kumabe T, Tominaga T, Collins VP, Cho YJ, Hoffman C, Lyden D, Wisoff JH, Garvin JH, Jr., Stearns DS, Massimi L, Schuller U, Sterba J, Zitterbart K, Puget S, Ayrault O, Dunn SE, Tirapelli DP, Carlotti CG, Wheeler H, Hallahan AR, Ingram W, MacDonald TJ, Olson JJ, Van Meir EG, Lee JY, Wang KC, Kim SK, Cho BK, Pietsch T, Fleischhack G, Tippelt S, Ra YS, Bailey S, Lindsey JC, Clifford SC, Eberhart CG, Cooper MK, Packer RJ, Massimino M, Garre ML, Bartels U, Tabori U, Hawkins CE, Dirks P, Bouffet E, Rutka JT, Wechsler-Reya RJ, Weiss WA, Collier LS, Dupuy AJ, Korshunov A, Jones DT, Kool M, Northcott PA, Pfister SM, Largaespada DA, Mungall AJ, Moore RA, Jabado N, Bader GD, Jones SJ, Malkin D, Marra MA, Taylor MD. Divergent clonal selection dominates medulloblastoma at recurrence. Nature. 2016;529(7586):351-7.

25. Korshunov A, Sturm D, Ryzhova M, Hovestadt V, Gessi M, Jones DT, Remke M, Northcott P, Perry A, Picard D, Rosenblum M, Antonelli M, Aronica E, Schuller U, Hasselblatt M, Woehrer A, Zheludkova O, Kumirova E, Puget S, Taylor MD, Giangaspero F, Peter Collins V, von Deimling A, Lichter P, Huang A, Pietsch T, Pfister SM, Kool M. Embryonal tumor with abundant neuropil and true rosettes (ETANTR), ependymoblastoma, and medulloepithelioma share molecular similarity and comprise a single clinicopathological entity. Acta Neuropathol. 2014;128(2):279-89.

26. Nobusawa S, Yokoo H, Hirato J, Kakita A, Takahashi H, Sugino T, Tasaki K, Itoh H, Hatori T, Shimoyama Y, Nakazawa A, Nishizawa S, Kishimoto H, Matsuoka K, Nakayama M, Okura N, Nakazato Y. Analysis of chromosome 19q13.42 amplification in embryonal brain tumors with ependymoblastic multilayered rosettes. Brain Pathol. 2012;22(5):689-97.

27. Wang Y, Chu SG, Xiong J, Cheng HX, Chen H, Yao XH. Embryonal tumor with abundant neuropil and true rosettes (ETANTR) with a focal amplification at chromosome 19q13.42 locus: further evidence of two new instances in China. Neuropathology. 2011;31(6):639-47.

28. Kleinman CL, Gerges N, Papillon-Cavanagh S, Sin-Chan P, Pramatarova A, Quang DA, Adoue V, Busche S, Caron M, Djambazian H, Bemmo A, Fontebasso AM, Spence T, Schwartzentruber J, Albrecht S, Hauser P, Garami M, Klekner A, Bognar L, Montes JL, Staffa A, Montpetit A, Berube P, Zakrzewska M, Zakrzewski K, Liberski PP, Dong Z, Siegel PM, Duchaine T, Perotti C, Fleming A, Faury D, Remke M, Gallo M, Dirks P, Taylor MD, Sladek R, Pastinen T, Chan JA, Huang A, Majewski J, Jabado N. Fusion of TTYH1 with the C19MC microRNA cluster drives expression of a brain-specific DNMT3B isoform in the embryonal brain tumor ETMR. Nat Genet. 2014;46(1):39-44.

29. Korshunov A, Ryzhova M, Jones DT, Northcott PA, van Sluis P, Volckmann R, Koster J, Versteeg R, Cowdrey C, Perry A, Picard D, Rosenblum M, Giangaspero F, Aronica E, Schuller U, Hasselblatt M, Collins VP, von Deimling A, Lichter P, Huang A, Pfister SM, Kool M. LIN28A immunoreactivity is a potent diagnostic marker of embryonal tumor with multilayered rosettes (ETMR). Acta Neuropathol. 2012;124(6):875-81.

30. Miller S, Ward JH, Rogers HA, Lowe J, Grundy RG. Loss of INI1 protein expression defines a subgroup of aggressive central nervous system primitive neuroectodermal tumors. Brain Pathol. 2013;23(1):19-27.

31. Torchia J, Golbourn B, Feng S, Ho KC, Sin-Chan P, Vasiljevic A, Norman JD, Guilhamon P, Garzia L, Agamez NR, Lu M, Chan TS, Picard D, de Antonellis P, Khuong-Quang DA, Planello AC, Zeller C, Barsyte-Lovejoy D, Lafay-Cousin L, Letourneau L, Bourgey M, Yu M, Gendoo DM, Dzamba M, Barszczyk M, Medina T, Riemenschneider AN, Morrissy AS, Ra YS, Ramaswamy V, Remke M, Dunham CP, Yip S, Ng HK, Lu JQ, Mehta V, Albrecht S, Pimentel J, Chan JA, Somers GR, Faria CC, Roque L, Fouladi M, Hoffman LM, Moore AS, Wang Y, Choi SA, Hansford JR, Catchpoole D, Birks DK, 
Foreman NK, Strother D, Klekner A, Bognar L, Garami M, Hauser P, Hortobagyi T, Wilson B, Hukin J, Carret AS, Van Meter TE, Hwang EI, Gajjar A, Chiou SH, Nakamura H, Toledano H, Fried I, Fults D, Wataya T, Fryer C, Eisenstat DD, Scheinemann K, Fleming AJ, Johnston DL, Michaud J, Zelcer S, Hammond R, Afzal S, Ramsay DA, Sirachainan N, Hongeng S, Larbcharoensub N, Grundy RG, Lulla RR, Fangusaro JR, Druker H, Bartels U, Grant R, Malkin D, McGlade CJ, Nicolaides T, Tihan T, Phillips J, Majewski J, Montpetit A, Bourque G, Bader GD, Reddy AT, Gillespie GY, Warmuth-Metz M, Rutkowski S, Tabori U, Lupien M, Brudno M, Schuller U, Pietsch T, Judkins AR, Hawkins CE, Bouffet E, Kim SK, Dirks PB, Taylor MD, Erdreich-Epstein A, Arrowsmith CH, De Carvalho DD, Rutka JT, Jabado N, Huang A. Integrated (epi)-Genomic Analyses Identify Subgroup-Specific Therapeutic Targets in CNS Rhabdoid Tumors. Cancer Cell. 2016;30(6):891-908.

32. Johann PD, Erkek S, Zapatka M, Kerl K, Buchhalter I, Hovestadt V, Jones DT, Sturm D, Hermann C, Segura Wang M, Korshunov A, Rhyzova M, Grobner S, Brabetz S, Chavez L, Bens S, Groschel S, Kratochwil F, Wittmann A, Sieber L, Georg C, Wolf S, Beck K, Oyen F, Capper D, van Sluis P, Volckmann R, Koster J, Versteeg R, von Deimling A, Milde T, Witt O, Kulozik AE, Ebinger M, Shalaby T, Grotzer M, Sumerauer D, Zamecnik J, Mora J, Jabado N, Taylor MD, Huang A, Aronica E, Bertoni A, Radlwimmer B, Pietsch T, Schuller U, Schneppenheim R, Northcott PA, Korbel JO, Siebert R, Fruhwald MC, Lichter P, Eils R, Gajjar A, Hasselblatt M, Pfister SM, Kool M. Atypical Teratoid/Rhabdoid Tumors Are Comprised of Three Epigenetic Subgroups with Distinct Enhancer Landscapes. Cancer Cell. 2016;29(3):379-93.

33. Muller K, Diez B, Muggeri A, Pietsch T, Friedrich C, Rutkowski S, von Hoff K, von Bueren AO, Zwiener I, Bruns F. What's in a name? Intracranial peripheral primitive neuroectodermal tumors and CNS primitive neuroectodermal tumors are not the same. Strahlentherapie und Onkologie : Organ der Deutschen Rontgengesellschaft [et al]. 2013;189(5):372-9.

34. Kazmi SA, Perry A, Pressey JG, Wellons JC, Hammers Y, Palmer CA. Primary Ewing sarcoma of the brain: a case report and literature review. Diagnostic molecular pathology : the American journal of surgical pathology, part B. 2007;16(2):108-11.

35. Gessi M, Gielen GH, Hammes J, Dorner E, Muhlen AZ, Waha A, Pietsch T. H3.3 G34R mutations in pediatric primitive neuroectodermal tumors of central nervous system (CNS-PNET) and pediatric glioblastomas: possible diagnostic and therapeutic implications? J Neurooncol. 2013;112(1):67-72.

36. Sturm D, Orr BA, Toprak UH, Hovestadt V, Jones DT, Capper D, Sill M, Buchhalter I, Northcott PA, Leis I, Ryzhova M, Koelsche C, Pfaff E, Allen SJ, Balasubramanian G, Worst BC, Pajtler KW, Brabetz S, Johann PD, Sahm F, Reimand J, Mackay A, Carvalho DM, Remke M, Phillips JJ, Perry A, Cowdrey C, Drissi R, Fouladi M, Giangaspero F, Lastowska M, Grajkowska W, Scheurlen W, Pietsch T, Hagel C, Gojo J, Lotsch D, Berger W, Slavc I, Haberler C, Jouvet A, Holm S, Hofer S, Prinz M, Keohane C, Fried I, Mawrin C, Scheie D, Mobley BC, Schniederjan MJ, Santi M, Buccoliero AM, Dahiya S, Kramm CM, von Bueren AO, von Hoff K, Rutkowski S, Herold-Mende C, Fruhwald MC, Milde T, Hasselblatt M, Wesseling P, Rossler J, Schuller U, Ebinger M, Schittenhelm J, Frank S, Grobholz R, Vajtai I, Hans V, Schneppenheim R, Zitterbart K, Collins VP, Aronica E, Varlet P, Puget S, Dufour C, Grill J, Figarella-Branger D, Wolter M, Schuhmann MU, Shalaby T, Grotzer M, van Meter T, Monoranu CM, Felsberg J, Reifenberger G, Snuderl M, Forrester LA, Koster J, Versteeg R, Volckmann R, van Sluis P, Wolf S, Mikkelsen T, Gajjar A, Aldape K, Moore AS, Taylor MD, Jones C, Jabado N, Karajannis MA, Eils R, Schlesner M, Lichter P, von Deimling A, Pfister SM, Ellison DW, Korshunov A, Kool M. New Brain Tumor Entities Emerge from Molecular Classification of CNS-PNETs. Cell. 2016;164(5):1060-72. 37. Friedrich C, von Bueren AO, von Hoff K, Gerber NU, Ottensmeier H, Deinlein F, Benesch M, Kwiecien R, Pietsch T, Warmuth-Metz M, Faldum A, Kuehl J, Kortmann RD, Rutkowski S. Treatment of young children with CNS-primitive neuroectodermal tumors/pineoblastomas in the prospective multicenter trial HIT 2000 using different chemotherapy regimens and radiotherapy. Neuro Oncol. 2013;15(2):224-34.

38. Parikh KA, Venable GT, Orr BA, Choudhri AF, Boop FA, Gajjar AJ, Klimo P, Jr. PineoblastomaThe Experience at St. Jude Children's Research Hospital. Neurosurgery. 2017.

39. Miller S, Rogers HA, Lyon P, Rand V, Adamowicz-Brice M, Clifford SC, Hayden JT, Dyer S, Pfister S, Korshunov A, Brundler MA, Lowe J, Coyle B, Grundy RG. Genome-wide molecular characterization of central nervous system primitive neuroectodermal tumor and pineoblastoma. Neuro Oncol. 2011;13(8):866-79.

40. de Kock L, Sabbaghian N, Druker H, Weber E, Hamel N, Miller S, Choong CS, Gottardo NG, Kees UR, Rednam SP, van Hest LP, Jongmans MC, Jhangiani S, Lupski JR, Zacharin M, Bouron-Dal Soglio D, Huang A, Priest JR, Perry A, Mueller S, Albrecht S, Malkin D, Grundy RG, Foulkes WD. Germline and somatic DICER1 mutations in pineoblastoma. Acta Neuropathol. 2014;128(4):583-95. 
41. Gielen GH, Gessi M, Denkhaus D, Pietsch T. CRX/OTX3: a useful marker in the differential diagnosis of tumors of the pineal region and indicator of photoreceptor differentiation in medulloblastomas and atypical teratoid rhabdoid tumors. Applied immunohistochemistry \& molecular morphology : AIMM. 2013;21(3):248-53.

42. Manila A, Mariangela N, Libero L, Francesca G, Romana BF, Felice G. Is CRX protein a useful marker in differential diagnosis of tumors of the pineal region? Pediatric and developmental pathology : the official journal of the Society for Pediatric Pathology and the Paediatric Pathology Society. 2014;17(2):85-8.

43. Homma T, Hemmi A, Ohta T, Kusumi Y, Yoshino A, Hao H. A rare case of a pineoblastoma with a rhabdomyoblastic component. Neuropathology. 2017;37(3):227-32.

44. Scheithauer BW, Horvath E, Abel TW, Robital Y, Park SH, Osamura RY, Deal C, Lloyd RV, Kovacs K. Pituitary blastoma: a unique embryonal tumor. Pituitary. 2012;15(3):365-73.

45. de Kock L, Sabbaghian N, Plourde F, Srivastava A, Weber E, Bouron-Dal Soglio D, Hamel N, Choi JH, Park SH, Deal CL, Kelsey MM, Dishop MK, Esbenshade A, Kuttesch JF, Jacques TS, Perry A, Leichter H, Maeder P, Brundler MA, Warner J, Neal J, Zacharin M, Korbonits M, Cole T, Traunecker $\mathrm{H}$, McLean TW, Rotondo F, Lepage P, Albrecht S, Horvath E, Kovacs K, Priest JR, Foulkes WD. Pituitary blastoma: a pathognomonic feature of germ-line DICER1 mutations. Acta Neuropathol. 2014;128(1):111-22.

46. Pietsch T, Haberler C. Update on the integrated histopathological and genetic classification of medulloblastoma - a practical diagnostic guideline. Clin Neuropathol. 2016;35(6):344-52. 


\begin{tabular}{|c|c|c|c|}
\hline \multicolumn{4}{|c|}{ A. Medulloblastoma, genetically defined } \\
\hline WHO & Histological & Special & Key molecular features \\
\hline $\begin{array}{l}\text { WNT } \\
\text { activated }\end{array}$ & Usually classic & $\begin{array}{l}\text { Nuclear } \beta \text {-catenin positive }(>5- \\
10 \% \text { of cells) } \\
\text { Nuclear YAP1 positive, } \\
\text { nuclear OTX2 positive } \\
\text { GAB1 negative, p75NGFR } \\
\text { negative }\end{array}$ & $\begin{array}{l}\text { Mutation in exon } 3 \text { of CTNNB1 } \\
\text { ( } \beta \text {-catenin) } \\
\text { Monosomy of chromosome } 6 \\
\text { Typical WNT profile on } \\
\text { methylation and transcriptome } \\
\text { analysis }\end{array}$ \\
\hline $\begin{array}{l}\text { SHH } \\
\text { activated, } \\
\text { TP53 } \\
\text { wildtype }\end{array}$ & $\begin{array}{l}\text { Any variant. } \\
\text { Includes all } \\
\text { nodular/desmopla } \\
\text { stic } \\
\text { medulloblastomas } \\
\text { and MBEN } \\
\end{array}$ & $\begin{array}{l}\text { No significant nuclear } \beta- \\
\text { catenin, } \\
\text { Nuclear YAP1 positive, } \\
\text { nuclear OTX2 negative, } \\
\text { GAB1 positive, p75NGFR } \\
\text { positive }\end{array}$ & $\begin{array}{l}\text { No mutation of TP53 } \\
\text { Typical SHH-profile on } \\
\text { methylation and transcriptome } \\
\text { analysis }\end{array}$ \\
\hline $\begin{array}{l}\text { SHH } \\
\text { activated, } \\
\text { TP53 } \\
\text { mutant }\end{array}$ & $\begin{array}{l}\text { Any variant, often } \\
\text { anaplastic }\end{array}$ & $\begin{array}{l}\text { No significant nuclear } \beta- \\
\text { catenin, } \\
\text { Nuclear YAP1 positive, } \\
\text { nuclear OTX2 negative, } \\
\text { GAB1 positive, p75NGFR } \\
\text { positive, } \\
\text { Mostly nuclear p53 positive }\end{array}$ & $\begin{array}{l}\text { Mutation of TP53 } \\
\text { Typical SHH-profile on } \\
\text { methylation and transcriptome } \\
\text { analysis } \\
\text { Frequently } M Y C N \text { or } G L / 2 \\
\text { amplification }\end{array}$ \\
\hline $\begin{array}{l}\text { Non- } \\
\text { WNT/non- } \\
\text { SHH } \\
\text { (Group 3 or } \\
\text { Group 4) }\end{array}$ & $\begin{array}{l}\text { Any variant } \\
\text { except } \\
\text { desmoplastic/nod } \\
\text { ular or MBEN }\end{array}$ & $\begin{array}{l}\text { No significant nuclear } \beta- \\
\text { catenin } \\
\text { Nuclear YAP1 negative, } \\
\text { nuclear OTX2 positive } \\
\text { GAB1 negative, p75NGFR } \\
\text { negative }\end{array}$ & $\begin{array}{l}\text { MYC or MYCN amplification in } \\
\text { some but not diagnostic } \\
\text { Typical Group } 3 \text { or Group } 4 \\
\text { profile on methylation and } \\
\text { transcriptome analysis }\end{array}$ \\
\hline
\end{tabular}

\begin{tabular}{|c|c|c|c|}
\hline \multicolumn{4}{|c|}{ B. Medulloblastoma, histologically defined } \\
\hline $\begin{array}{l}\text { WHO } \\
\text { entity }\end{array}$ & $\begin{array}{l}\text { Histological } \\
\text { features }\end{array}$ & $\begin{array}{l}\text { Special stains/ } \\
\text { immunohistochemistry }\end{array}$ & Key molecular features \\
\hline Classic & $\begin{array}{l}\text { Lacks } \\
\text { intratumoural } \\
\text { desmoplasia or } \\
\text { significant (diffuse } \\
\text { and severe) } \\
\text { anaplasia } \\
\end{array}$ & $\begin{array}{l}\text { Reticulin staining shows a lack } \\
\text { of nodular desmoplasia }\end{array}$ & $\begin{array}{l}\text { Frequent phenotype across all } \\
4 \text { molecular categories }\end{array}$ \\
\hline $\begin{array}{l}\text { Desmoplas } \\
\text { tic/ Nodular }\end{array}$ & $\begin{array}{l}\text { Nodular with } \\
\text { internodular } \\
\text { desmoplasia, can } \\
\text { be present in } \\
\text { minor areas only }\end{array}$ & $\begin{array}{l}\text { Reticulin staining highlights } \\
\text { internodular desmoplasia. } \\
\text { SHH phenotype (nuclear } \\
\text { YAP1 positive, GAB1 positive, } \\
\text { p75NGFR positive, nuclear } \\
\text { OTX2 negative, no significant } \\
\text { nuclear } \beta \text {-catenin) }\end{array}$ & $\begin{array}{l}\text { SHH-activated molecular } \\
\text { profiles }\end{array}$ \\
\hline $\begin{array}{l}\text { Medullobla } \\
\text { stoma with } \\
\text { extensive } \\
\text { nodularity }\end{array}$ & $\begin{array}{l}\text { Abundant and } \\
\text { large irregular } \\
\text { nodules with } \\
\text { internodular } \\
\text { desmoplasia }\end{array}$ & $\begin{array}{l}\text { Reticulin staining highlights } \\
\text { internodular desmoplasia. } \\
\text { Advanced neurocytic } \\
\text { differentiation in islands with } \\
\text { strong nuclear NeuN } \\
\text { expression. } \\
\text { SHH phenotype (nuclear } \\
\text { YAP1 positive, GAB1 positive, } \\
\text { p75NGFR positive, nuclear } \\
\text { OTX2 negative, no significant } \\
\text { nuclear } \beta \text {-catenin) }\end{array}$ & $\begin{array}{l}\text { SHH-activated molecular } \\
\text { profiles }\end{array}$ \\
\hline
\end{tabular}




\begin{tabular}{|c|c|c|c|}
\hline $\begin{array}{l}\text { Large } \\
\text { cell/anapla } \\
\text { stic }\end{array}$ & $\begin{array}{l}\text { Predominant } \\
\text { large cell and/or } \\
\text { anaplastic } \\
\text { phenotype of } \\
\text { tumour cells }\end{array}$ & $\begin{array}{l}\text { Large cell cytology is } \\
\text { frequently associated with dot- } \\
\text { like synaptophysin expression. } \\
\text { P53 accumulation may hint to } \\
\text { SHH-activated cases with } \\
\text { TP53 mutation. }\end{array}$ & $\begin{array}{l}\text { Mostly non-WNT/non-SHH } \\
\text { molecular profiles, also in SHH } \\
\text { medulloblastoma, TP53 } \\
\text { mutated. } \\
\text { Frequent MYC gene } \\
\text { amplification in tumour with } \\
\text { large cell phenotype. } \\
\text { Anaplasia may hint to TP53 } \\
\text { mutated SHH activated } \\
\text { medulloblastomas. }\end{array}$ \\
\hline
\end{tabular}




\begin{tabular}{|c|c|}
\hline WHO entity & Diagnostic investigations \\
\hline ETMR, C19MC altered & $\begin{array}{l}\text { LIN28A positive [IHC] } \\
\text { C19MC amplification [FISH or array] or fusion (RT-PCR) }\end{array}$ \\
\hline ETMR, NOS & $\begin{array}{l}\text { Multilayered ependymoblastic rosettes but C19MC alteration either } \\
\text { not detected or testing for this alteration not undertaken }\end{array}$ \\
\hline Medulloepithelioma & $\begin{array}{l}\text { LIN28A positive } \\
\text { No detectable C19MC amplification }\end{array}$ \\
\hline AT/RT & $\begin{array}{l}\text { SMARCB1 or SMARCA4 loss [IHC sufficient, can be confirmed by } \\
\text { sequencing but not required] }\end{array}$ \\
\hline $\begin{array}{l}\text { CNS embryonal } \\
\text { tumour with rhabdoid } \\
\text { features }\end{array}$ & SMARCB1 and SMARCA4 retained but showing rhabdoid features \\
\hline CNS neuroblastoma & $\begin{array}{l}\text { Immunohistochemical evidence for neuroblastic/neuronal } \\
\text { differentiation (synaptophysin-positive) } \\
\text { LIN28A negative, SMARCB1 and SMARCA4 retained }\end{array}$ \\
\hline $\begin{array}{l}\text { CNS } \\
\text { ganglioneuroblastoma }\end{array}$ & $\begin{array}{l}\text { Immunohistochemically similar to CNS neuroblastoma but with } \\
\text { groups of prominent ganglion cells } \\
\text { LIN28A negative, SMARCB1 and SMARCA4 retained }\end{array}$ \\
\hline $\begin{array}{l}\text { CNS embryonal } \\
\text { tumour, NOS }\end{array}$ & $\begin{array}{l}\text { Requires active exclusion of other diagnoses: } \\
\text { - AT/RT: SMARCB1 and SMARCA4 intact } \\
\text { - ETMR: no LIN28A expression or C19MC amplification } \\
\text { - Soft tissue tumours/Ewing's sarcoma: no membranous CD99 } \\
\text { [IHC], EWSR1 or CIC/NUT rearrangement not present [FISH, RNA- } \\
\text { seq] } \\
\text { - Ependymoma: no C11orf95-RELA fusion [FISH], L1CAM and/or } \\
\text { nuclear p65/RelA expression [IHC] } \\
\text { - High grade astrocytoma: no mutations in } H 3.1, H 3.3, A T R X, \\
\text { IDH1/2 [IHC, sequencing needed to exclude the presence of } H 3 F 3 A \\
\text { G34 mutation] } \\
\text { - Consider methylation profiling }\end{array}$ \\
\hline
\end{tabular}


WHO 2007

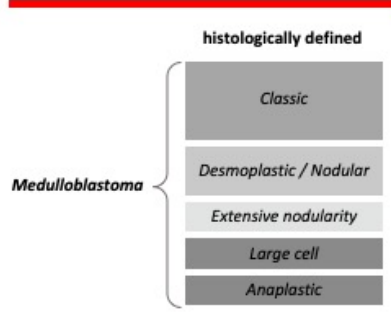

AT/RT
CNS PNET $\left\{\begin{array}{c}\text { Atypical teratoid/ } \\ \text { rhabdoid tumour }\end{array}\right.$
$\begin{gathered}\text { Ependymoblastoma } \\ \text { Medulloepithelioma }\end{gathered}$
$\begin{gathered}\text { CNS neuroblastoma } \\ \text { CNS } \\ \text { ganglioneuroblastoma }\end{gathered}$
WHO 2016

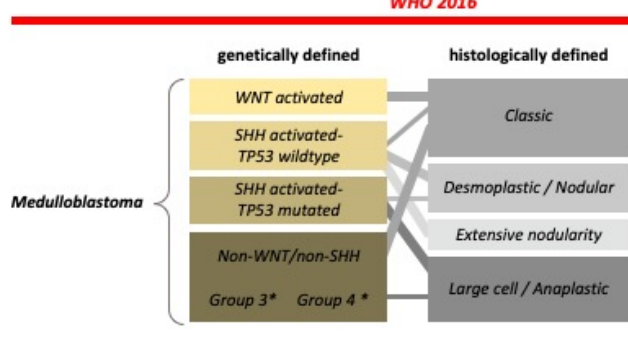

ET with rhabdoid

Atypical teratoid/
rhabdoid tumour

features

ET with multilayered
rosettes $\left\{\begin{array}{l}\text { ETMR C19MC-altered } \\ \text { ET }\end{array}\right.$

other
embryonal tumours
CNS embryonal tumour
with rhadoid features*

\begin{tabular}{|l|l}
\hline ETMR, NOS* & Embryonal tumour, NOS \\
\hline
\end{tabular}

Medulloepithelioma

CNS neuroblastoma $\quad$ provisional subentity

NOS $=$ not otherwise specified
grey lines indicate most

grey lines indicate most prominent
associations between histological and 